\title{
Closing of the First International Congress on Complementary and Alternative Treatments in Cancer
}

\section{Support for Evidence-Based CAMs and Criticism of Conventional latrogenic Cancer Treatments}

\author{
José Antonio Campoy and Antonio Muro
}

\author{
Discovery Salud (www.dsalud.com), c/Mirasierra, 5. Atico A. 28220 Majadahonda, Madrid, Spain
}

A standing ovation of some 1200 people bidding farewell to the speakers was the closing act of the first International Conference on Complementary and Alternative Treatments in Cancer. The conference was held on May 14 and 15, 2005, in the auditorium of the Madrid Palace of Congress and Exhibitions in Spain. Hundreds of doctors-including more than 100 oncologists, biologists, specialist engineers in electromedicine, representatives of numerous laboratories, alternative health care professionals, and other experts-left with the conviction that as the first of its kind in the world, this event will epitomize the before and after of cancer treatment.

The conclusion was resounding: each year the number of people who die of cancer increases and although the pharmaceutical industry periodically puts out unrepresentative information, with the media's involvement or ignorance, it is evident that orthodox cancer treatments such as chemotherapy, radiotherapy, and surgery have failed. Therefore, the time has come for a sweeping change in therapies for this illness.

The opening report of the congress demolished all opposition by showing beyond any doubt the scientific validity of all the alternative treatments presented, which are innocuous and have noticeably higher efficacy than radiotherapy and chemotherapy. This cast serious doubt on the credibility of those who try to scorn alternative treatments.

This fact was established in many presentations, using the same arguments as orthodox clinical oncology studies that adhere to a protocol. This overcame all challenges. Unlike traditional congresses, the palace's auditorium was completely filled during the 15 presentations, all of which were interrupted several times by prolonged approving applause.

For reprints and all correspondence: José Antonio Campoy, Discovery Salud, c/Mirasierra, 5. Atico A. 28220 Majadahonda, Madrid, Spain. Tel: +34-916382728; Fax: +34-91-6384043; E-mail: redaccion@dsalud.com
Those who attended were amazed by the excellence of the presentations, their medical and scientific quality, and the human value of the lecturers. However, four of the presentations stand out for particularly poignant moments. The first moment came with the participation of Dr Salvador Capistrán, who is very well known in Mexico and who could not curb his emotion during the lecture, transmitting it to the hundreds present.

The long ovation that closed his lecture prompted a number of those attending to ask the organizers whether it could be repeated. Unfortunately, this was not possible owing to the event's very tight agenda. Dr Capistrán's large medical staff in Mexico is treating cancer with excellent results using antigen vaccines processed from the patient's urine.

The second moment occurred when, during the presentation by Dr Jaroslaw W. Nowicky, Director of the Ukrainian AntiCancer Institute of Vienna (Austria), the congress organizers announced his nomination by colleagues for the Nobel Prize in Chemistry. When it is injected intravenously in therapeutic doses, Ukrain destroys carcinogenic cells by stimulating their 'suicide' or apoptosis without affecting healthy cells. Ukrain has been the object of investigations and studies by 159 scientists from 56 universities in 26 different countries. Results have been presented in 220 international scientific congresses and symposia. Details of the properties of Ukrain have been published in 192 scientific publications. Thus, an enthusiastic response ended Dr Nowicky's presentation.

The third momentous occasion was when the council of the Discovery Salud journal, organizer and sponsor of this congress, announced that it would propose Dr Ryke Geerd Hamer for the Nobel Prize in Medicine. 'Those legally entitled to do so will not do it,' said José Antonio Campoy, Director of Discovery Salud.

(C) The Author (2005). Published by Oxford University Press. All rights reserved.

The online version of this article has been published under an open access model. Users are entitled to use, reproduce, disseminate, or display the open access version of this article for non-commercial purposes provided that: the original authorship is properly and fully attributed; the Journal and Oxford University Press are attributed as the original place of publication with the correct citation details given; if an article is subsequently reproduced or disseminated not in its entirety but only in part or as a derivative work this must be clearly indicated. For commercial re-use, please contact journals.permissions@oupjournals.org 
In fact, the prize's criteria restrict the possibility of nomination and it is obvious that candidates can only be proposed by those who belong to the system. What Hammer proposes is not, in any way, in the interests of those opposed to him, who live from the business of making money out of health, and thus he will not be taken into consideration. So, although the policy does not allow it, we will try to bring about his nomination through popular request. Therefore, we will facilitate, for this reason, a place for this at our web site www.dsalud. com. This initiative will be communicated to him today as his birthday is tomorrow. The idea was greeted with lengthy applause.

The final choice among many outstanding moments during the congress was the closing lecture concerning Bio-Bac. In an inspired presentation, Dr Fermín Moriano recounted the ignominious treatment of this product - which started 20 years ago in 1985, and which should have sent several public servants to prison-and also enumerated the numerous preclinical and clinical studies of Bio-Bac, including those undertaken at first-line centers in Germany and Belgium (together with Phase I, II, and III trials in osteoarthritis and AIDS).

Facts emerged about the public administration's two-and-ahalf-year 'Operation Witchcraft' against Bio-Bac; the health ministry's refusal to furnish an official answer concerning the clinical studies in its hands, as requested by the judge; and the authorities' initial claim that the studies did not exist and later allegation that they had been forged. The lecture triggered a standing ovation for the owner of the product, Rafael Chacón, when he was introduced by the moderator.

It must be added that all the health professionals present at the congress openly expressed their satisfaction with all the presentations and with developments at the event. These included the participation of Aleksandra Niedzwiecki, Doctor of Biochemistry, Executive Vice President and Investigation Director of Matias Rath Inc. (USA) and formerly Director of Cardiovascular Investigation at the Linus Pauling Science and Medicine Institute in Palo Alto, whose lecture dealt with 'New and effective focus for cellular medicine concerning metastasis and cancer growth'. Dr Eduardo Sanz, biologist, graduate in molecular oncology, Alfred Gilman's collaborator in the construction of the proteome, and currently scientific adviser to the Catalysis Laboratory, spoke about 'Virus factors in the development of tumors: new therapeutic alternatives'. Dr Hans Peter Weber, member of the consulting board of the International Society for the Investigation of Cellular Therapy and of the International Academy of Preventive Medicine, presented 'Effectiveness in the treatment of tumors with electrotherapy: scientific basis and real cases'. The worldrenowned Colombian Dr Jorge Carvajal, creator of Sintergetic Medicine, who has trained more than a thousand doctors from 11 different countries, spoke about 'Bio-energetic treatment of cancer'. The Uruguayan Dr Bernardo Udaquiola, member of the National Oncology Institute of Uruguay, presented 'Phototherapeutic and homeopathic treatment of cancer: Green Sap and Onconat'. The Ecuadorian Dr Edwin Ceballos, oncology and radiotherapy specialist, creator of the Biological Immune Response Modulator (BIRM), which has been approved by the FDA as an orphan treatment in pancreatic cancer, gave an account of 'BIRM in AIDS and cancer'. Professor Panos T. Pappas, international expert in electromagnetism and electrodynamics and adviser to the most important journals in these areas of expertise, spoke about 'The Pap-imi treatment in cancer'. The Director of the Spanish Center for Investigation and Diagnosis INSAODYT, Juan Prada, lectured on 'The possibilities of the biohematological exam', a method developed by his father, Dr Pascual Prada, 40 years ago, as an essential complementary diagnosis in cancer treatments.

José Olalde, jointly with Drs Meyer Magarici, José Gregorio Guiadas, Alberto Muhammad, and Antonio Salom, presented 'The Systemic Theory of Living Systems applied to cancer and results'. José Ramón Llorente, President of the Spanish Orthomolecular Nutrition Association, talked on 'The treatment of cancer with orthomolecular medicine'. The Italian expert Marco Pfister substituted for the speaker of honor of the congress, Dr Hammer. The Discovery Salud organization announced the following next steps: the publication of a book in September with all the information presented during the congress, as well as all other therapies published in the journal in the past 3 years, and the launch of a free health information service through the Internet with an initial projection of 1.5 million users. 


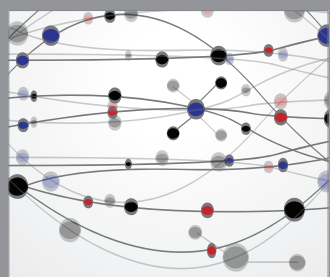

The Scientific World Journal
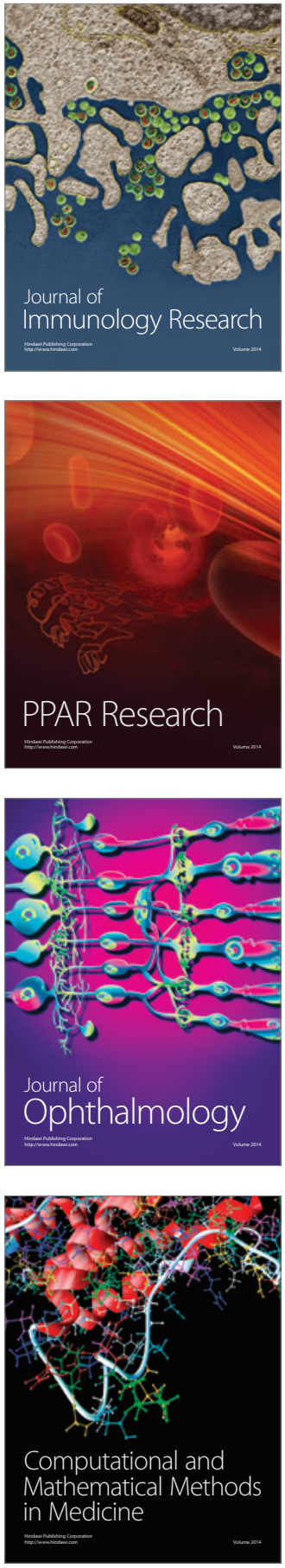

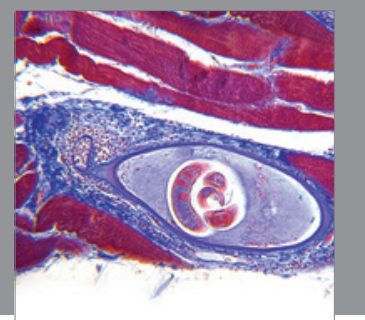

Gastroenterology

Research and Practice
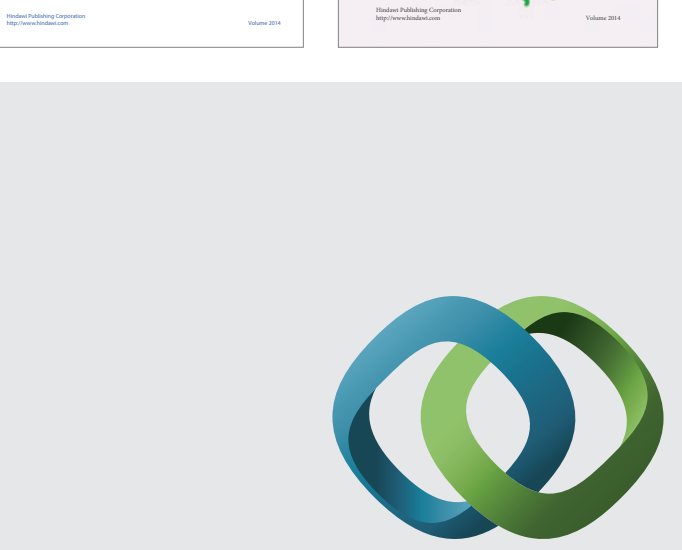

\section{Hindawi}

Submit your manuscripts at

http://www.hindawi.com
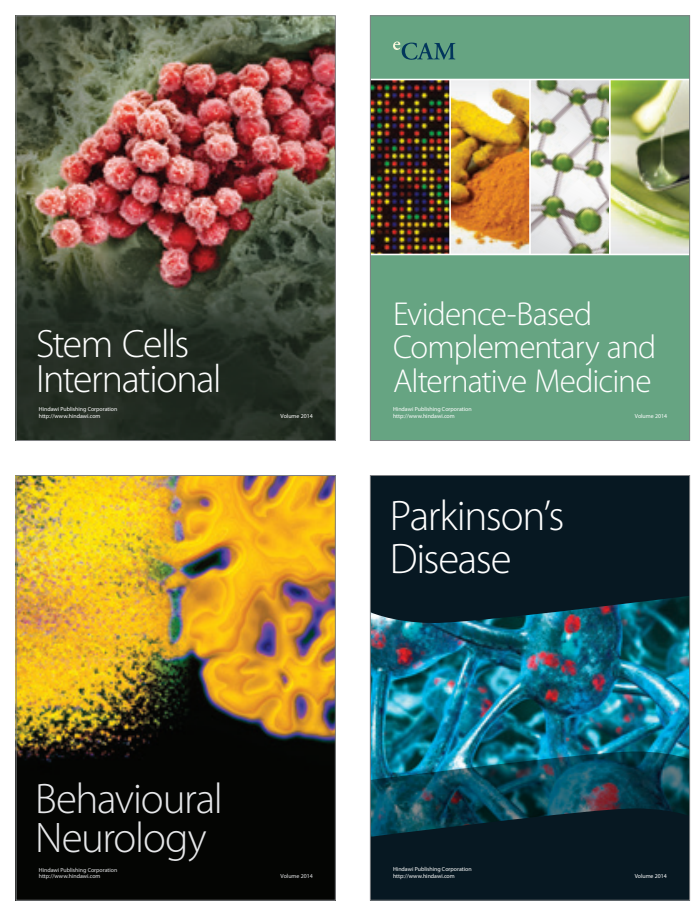

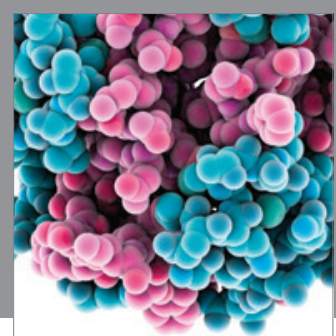

Journal of
Diabetes Research

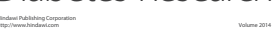

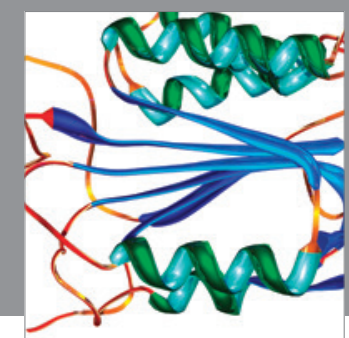

Disease Markers
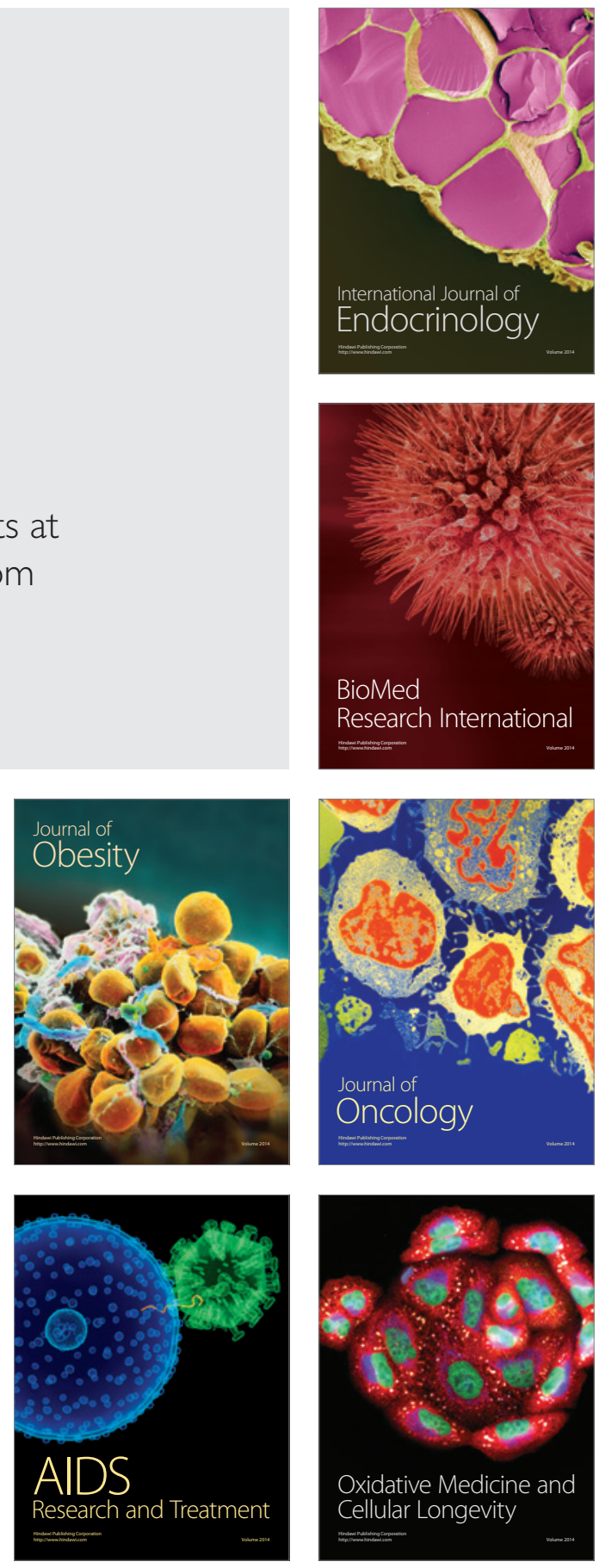